Article

\title{
Immobilization of the $\beta$-fructofuranosidase from Xanthophyllomyces dendrorhous by Entrapment in Polyvinyl Alcohol and Its Application to Neo-Fructooligosaccharides Production
}

\author{
Noa Míguez ${ }^{1}$, María Gimeno-Pérez ${ }^{2}$, David Fernández-Polo ${ }^{1}$, Fadia V. Cervantes ${ }^{1}$, \\ Antonio O. Ballesteros ${ }^{1}$, María Fernández-Lobato ${ }^{2}{ }^{(D)}$, María H. Ribeiro ${ }^{3}{ }^{(D)}$ and \\ Francisco J. Plou 1,* id \\ 1 Instituto de Catálisis y Petroleoquímica, CSIC, 28049 Madrid, Spain; noa.miguez@csic.es (N.M.); \\ david.fernandezpolo@estudiante.uam.es (D.F.-P.); fadiacervantes@gmail.com (F.V.C.); \\ a.ballesteros@icp.csic.es (A.O.B.) \\ 2 Centro de Biología Molecular Severo Ochoa, CSIC-UAM, 28049 Madrid, Spain; \\ mgimeno@cbm.csic.es (M.G.-P.); mfernandez@cbm.csic.es (M.F.-L.) \\ 3 Research Institute for Medicines (iMed.ULisboa), Faculdade de Farmácia, Universidade Lisboa, \\ 1649-003 Lisboa, Portugal; mhribeiro@ff.ulisboa.pt \\ * Correspondence: fplou@icp.csic.es; Tel.: +34-91-585-4869
}

Received: 21 April 2018; Accepted: 9 May 2018; Published: 11 May 2018

\begin{abstract}
The $\beta$-fructofuranosidase (Xd-INV) from the basidiomycota yeast Xanthophyllomyces dendrorhous (formerly Phaffia rhodozyma) is unique in its ability to synthesize neo- fructooligosaccharides (neo-FOS). In order to facilitate its industrial application, the recombinant enzyme expressed in Pichia pastoris (pXd-INV) was immobilized by entrapment in polyvinyl alcohol (PVA) hydrogels. The encapsulation efficiency exceeded $80 \%$. The PVA lenticular particles of immobilized pXd-INV were stable up to approximately $40{ }^{\circ} \mathrm{C}$. Using $600 \mathrm{~g} / \mathrm{L}$ sucrose, the immobilized biocatalyst synthesized $18.9 \%(w / w)$ FOS $(59.1 \mathrm{~g} / \mathrm{L}$ of neokestose, $30.2 \mathrm{~g} / \mathrm{L}$ of 1 -kestose, $11.6 \mathrm{~g} / \mathrm{L}$ of neonystose and $12.6 \mathrm{~g} / \mathrm{L}$ of blastose). The operational stability of PVA-immobilized biocatalyst was assayed in a batch reactor at $30^{\circ} \mathrm{C}$. The enzyme preserved its initial activity during at least 7 cycles of $26 \mathrm{~h}$.
\end{abstract}

Keywords: glycosidases; fructooligosaccharides; prebiotics; enzyme entrapment; immobilization; bioreactors; hydrogels; neokestose

\section{Introduction}

Fructooligosaccharides (FOS) are fructose oligomers linked to a sucrose skeleton by different $\beta(2 \rightarrow 1)$ or $\beta(2 \rightarrow 6)$ glycosidic bonds [1]. In addition to their prebiotic properties-which promote the development of bifidobacteria and lactobacillus in the gastrointestinal tract [2] —and their low glycemic index, FOS may exert other benefits in human health, including a better gut absorption of $\mathrm{Ca}^{2+}$ and $\mathrm{Mg}^{2+}$, a reduction of blood lipid levels and a reduced risk of suffering colon cancer $[3,4]$. FOS can be synthesized from sucrose by a transfructosylation reaction [5]. Commercial FOS possess an inulin-type structure containing $\beta(2 \rightarrow 1)$ linked fructose units [6]. However, it has been reported that neo-FOS, in which one fructosyl moiety is $\beta(2 \rightarrow 6)$ linked to the glucose unit of sucrose, could display improved prebiotic and physicochemical properties with regard to inulin-type FOS [7,8].

The $\beta$-fructofuranosidase Xd-INV from the yeast Xanthophyllomyces dendrorhous (formerly Phaffia rhodozyma) is a dimeric glycoprotein with a molecular mass of 320-380 kDa, which belongs to the glycoside hydrolase (GH) family 32 [9,10]. Like other $\beta$-fructofuranosidases, Xd-INV 
catalyzes both the hydrolysis of sucrose and the synthesis of FOS [11,12]. However, Xd-INV is unique in its ability to catalyze the transfer a fructosyl moiety to the 6-OH hydroxyl of glucose unit in sucrose. In fact, this is the most efficient enzyme reported for the production of neo-FOS (basically neokestose and neonystose) $[11,13]$. Xd-INV is an attractive enzyme not only for the production of neo-FOS, but also for the preparation of novel fructosylated derivatives [13]. Recently we successfully expressed this enzyme in Pichia pastoris (pXd-INV) yielding a significant volumetric activity [12].

Despite the enormous potential of biocatalytic processes [14], the industrial application of enzymes is often hampered by a lack of long-term operational stability and the difficulties to recover and reuse the biocatalysts [15]. Enzyme immobilization can help to overcome these drawbacks, since it allows the easy separation of the biocatalyst facilitating product recovery, which is commonly accompanied by the stabilization effect towards denaturation by high temperatures, extreme $\mathrm{pHs}$ or organic cosolvents [16,17].

Immobilization methodologies for industrial biotransformations should be relatively simple, inexpensive and provide active biocatalysts with substantial stability [15]. The strategies for enzyme immobilization are commonly classified into three groups [18]: support binding (by adsorption or covalent linkages), entrapment and cross-linking. For reactions involving the transformation of carbohydrates, covalent binding is preferred over adsorption to avoid enzyme leakage [19], but most of the commercial activated carriers are expensive [20-22]. Cross-linking gives rise to biocatalysts with highly concentrated enzyme activity, significant stability and low production costs due to the absence of carrier, although the recovery of activity is commonly low [14,15]. Entrapment is an efficient and inexpensive technique, which is very useful when substrates and products have low molecular sizes and high diffusion rates, as occurs with simple sugars $[14,23,24]$. The entrapment in hydrogels can be combined with cross-linking in order to provide more resistant biocatalysts $[25,26]$.

In this work, we have investigated the immobilization of recombinant pXd-INV to facilitate its industrial application in the production of neo-FOS and other fructosylated derivatives. Considering that the size of Xd-INV is significantly large (it is a dimeric enzyme with an average molecular mass of $360 \mathrm{kDa}$ and dimensions $135 \times 75 \times 45 \AA$ [10]), we believed that entrapment methodologies could be appropriate for this enzyme as the leakage through pores should be restricted Our focus was to evaluate polyvinyl alcohol (PVA) entrapment as an immobilization strategy. PVA is cheap, mechanically robust and nontoxic to organisms [27]. The efficiency of this methodology was assessed in terms of the recovered activity and operational stability. The resulting biocatalysts were applied to the production of neo-FOS.

\section{Results and Discussion}

\subsection{Immobilization of $p X d-I N V$ in PVA Hydrogels}

The recombinant $\beta$-fructofuranosidase $\mathrm{pXd}-\mathrm{INV}$ from $X$. dendrorhous was immobilized by entrapment in lenses of polyvinyl alcohol (PVA), as represented in Figure 1. The enzyme was mixed with a solution of PVA, and the gelification was accomplished by dripping the mixture onto a surface (96-well microplate) followed by partial drying at $50{ }^{\circ} \mathrm{C}$ [28]. The gelification can be also promoted by freezing and thawing [29,30] or by UV radiation [31]. The entrapment in highly elastic and stable hydrogels formed by PVA has given excellent results with glycosidic enzymes [26,30,32]. The gelation takes place by the formation of hydrogen bonds between the hydroxyl groups of the PVA, resulting in a noncovalent spatial network [33]. These hydrogels are also very useful in controlled drug release, artificial tissues, bioseparations or biosensors [34,35]. PVA-based biocatalysts have proven remarkable operational and mechanical stability in different types of bioreactors, including shaken microtiter plates, batch stirred tanks and packed-bed reactors [32]. 
Table 1 summarizes the main immobilization parameters using 10\% (w/v) PVA in $100 \mathrm{mM}$ sodium acetate ( $\mathrm{pH}$ 5.0), the optimum buffer for this enzyme. Two different enzyme loadings were assayed. Lens volume ranged 52-56 $\mu \mathrm{L}$. An increment of the initial enzyme activity did not result in a significant increase of the volumetric activity of the biocatalyst. In contrast, the recovered activity was substantially diminished compared with lower enzyme loadings. We checked by successive washings that pXd-INV was not released from the PVA hydrogels. Considering that this enzyme is quite stable under the immobilization conditions, we believe that a high enzyme concentration inside the PVA lenses may cause some diffusional limitations, thus explaining the results obtained when increasing the enzyme loading. Starting from 35.5 enzyme units (measured in the DNS assay) and $5 \mathrm{~mL}$ PVA solution, the encapsulation efficiency was satisfactory $(>80 \%)$.

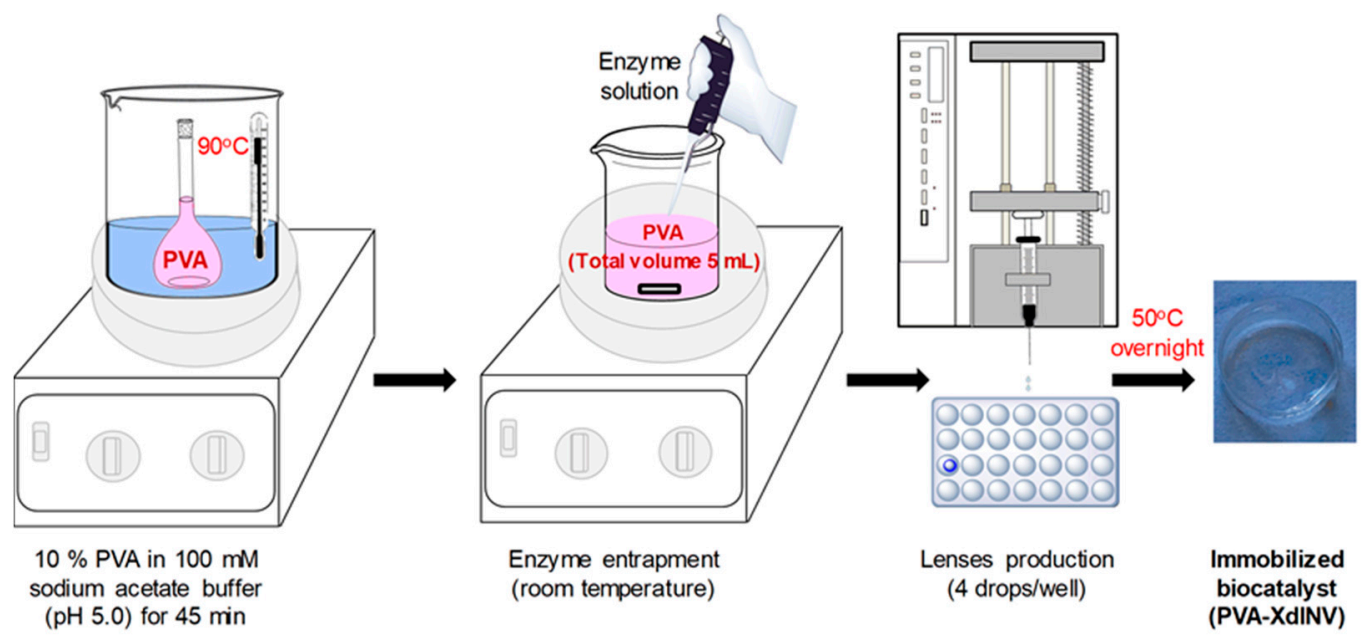

Figure 1. Immobilization of pXd-INV by entrapment in polyvinyl alcohol (PVA).

Table 1. Effect of pXd-INV enzyme loading on the activity and recovery upon immobilization by entrapment in PVA hydrogels.

\begin{tabular}{|c|c|c|c|c|c|}
\hline $\begin{array}{c}\text { Total Initial } \\
{\text { Activity }(U)^{a}}^{a}\end{array}$ & $\begin{array}{c}\text { Volume of } \\
\text { Biocatalyst }(\mathrm{mL})\end{array}$ & Lens Volume $(\mu \mathrm{L})^{b}$ & $\begin{array}{c}\text { Activity of the } \\
\text { Biocatalyst (U/lens) a }\end{array}$ & $\begin{array}{c}\text { Activity of the } \\
\text { Biocatalyst (U/ml) a }\end{array}$ & Recovered Activity (\%) \\
\hline 35.5 & 4.8 & 56.3 & 0.34 & 5.96 & 80.6 \\
\hline 84.5 & 4.7 & 52.6 & 0.33 & 6.20 & 34.5 \\
\hline
\end{tabular}

${ }^{a}$ Measured by the DNS assay; ${ }^{b}$ Lens volume $=($ volume dispensed/number of drops dispensed $) \times$ number of drops in each lens; ${ }^{c}($ Activity of the biocatalyst $\times$ Volume of biocatalyst obtained $\times 100) /$ Total activity introduced.

The operational stability of the biocatalyst obtained with the lowest enzyme loading ( $35.5 \mathrm{U}$ ) was assayed following a micro-scale procedure previously described by our group [36]. We performed 10 reaction cycles of $20 \mathrm{~min}$ with $100 \mathrm{mg} / \mathrm{mL}$ sucrose as substrate at $50{ }^{\circ} \mathrm{C}$, measuring the amount of reducing sugars by the DNS method (Figure 2). Between cycles, the biocatalyst was thoroughly washed with $100 \mathrm{mM}$ sodium acetate buffer ( $\mathrm{pH}$ 5.0). As shown, the operational stability of PVA-lens shaped particles was very satisfactory during at least 10 short cycles. 


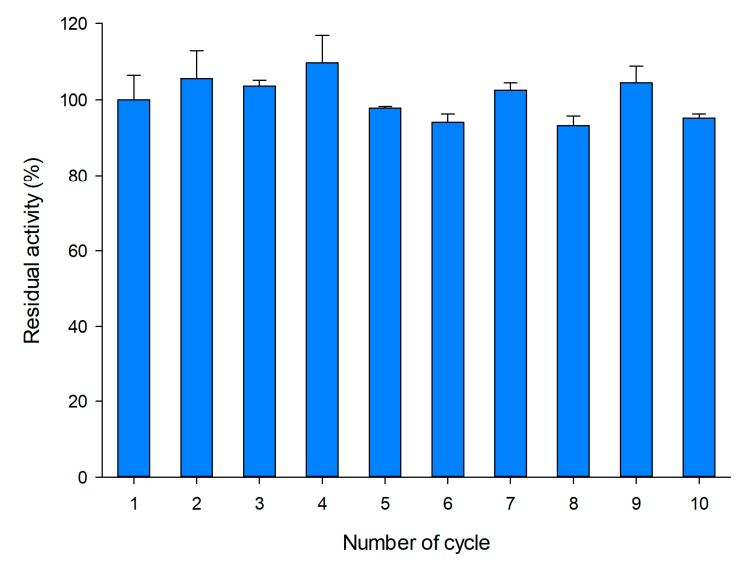

Figure 2. Operational stability of entrapped pXd-INV in PVA. Conditions for each cycle: $100 \mathrm{mg} / \mathrm{mL}$ sucrose, $50{ }^{\circ} \mathrm{C}, 20 \mathrm{~min}$ reaction.

\subsection{Production of FOS by Entrapped $p X d-I N V$}

Using $600 \mathrm{~g} / \mathrm{L}$ substrate, we analyzed the production of fructooligosaccharides catalyzed by immobilized pXd-INV. A high concentration of sucrose favours transglycosylation reaction in detriment of hydrolysis of the disaccharide [37]. The profile of the reaction products was characterized by High Performance Anion-Exchange Chromatography with Pulsed Amperometric Detection (HPAEC-PAD) (Figure 3). The products pattern correlated well with that obtained using the soluble enzyme expressed in P. pastoris [12]. Using neo-FOS standards purified and characterized as described in previous works [11,38], we were able to identify neokestose (the major product), 1-kestose and neonystose. Peak 5 was blastose [Fru- $\beta-(2 \rightarrow 6)-G l c]$, a sucrose isomer member of the neo-FOS series, which is produced by the hydrolysis of neokestose. We demonstrated in previous publications that Xd-INV was unable to transfer the fructosyl moiety to free glucose [11,12]. The structure of the FOS synthesized by immobilized pXd-INV is depicted in Figure 4.

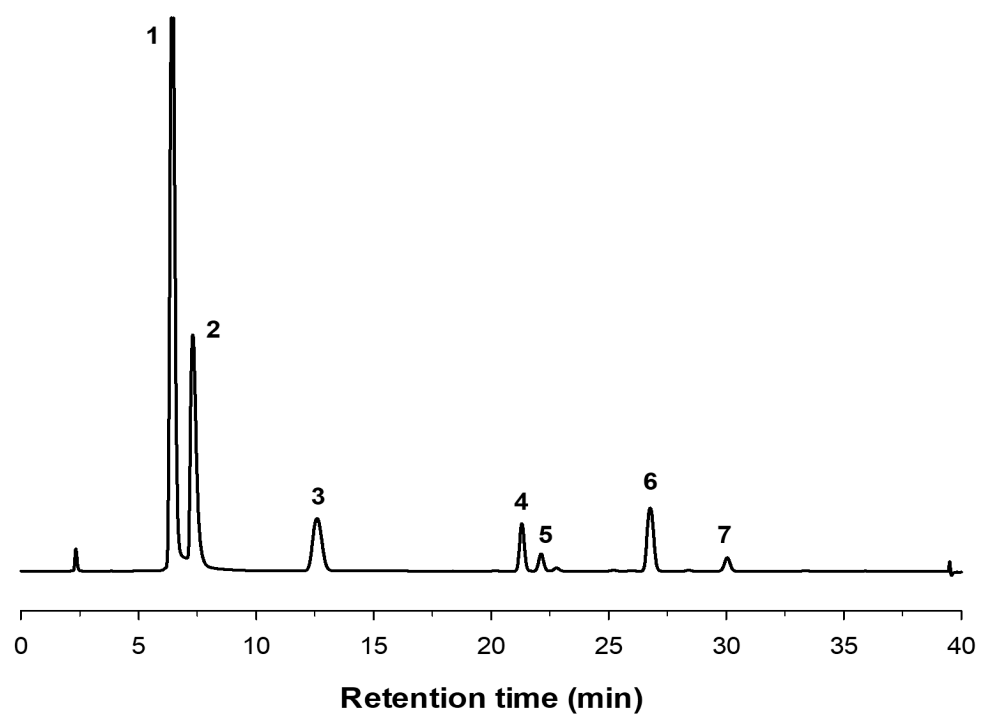

Figure 3. HPAEC-PAD chromatogram of the reaction of $600 \mathrm{~g} / \mathrm{L}$ sucrose at $50{ }^{\circ} \mathrm{C}$ with pXd-INV entrapped in PVA. (1) Glucose; (2) Fructose; (3) Sucrose; (4) 1-Kestose; (5) Blastose; (6) Neokestose; (7) Neonystose. 

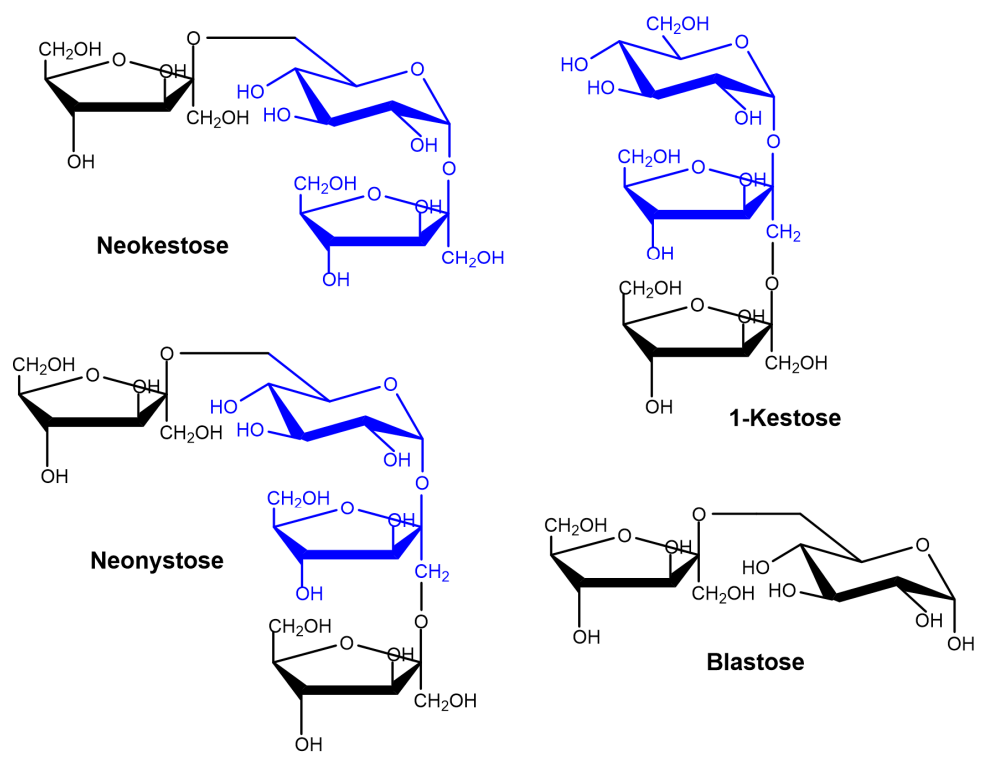

Figure 4. Structure of the FOS synthesized by immobilized pXd-INV. The sucrose skeleton is represented in blue.

\subsection{Thermal Stability of PVA Lens-Shaped Particles}

The operational stability represented in Figure 2 corresponded to short reaction cycles $(20 \mathrm{~min})$ at $50{ }^{\circ} \mathrm{C}$. The optimum temperature for both native and recombinant $\mathrm{Xd}-\mathrm{INV}$ is in the range $50-60{ }^{\circ} \mathrm{C}[11,12]$. However, in order to assess the potential of the immobilized pXd-INV biocatalysts for the synthesis of neo-FOS, we should consider the thermostability of the PVA lens-shaped particles in long-term operation. Thus, the immobilized biocatalyst was incubated at different temperatures $\left(4-60^{\circ} \mathrm{C}\right)$ for $24 \mathrm{~h}$ at $\mathrm{pH} 5.0$, and the residual activity was measured by the DNS assay (Figure 5). As shown, the activity of the PVA-lens shaped particles was maintained up to approximately $40{ }^{\circ} \mathrm{C}$. At higher temperatures, more than half of the activity was lost in one cycle. However, the soluble enzyme is very stable up to $60^{\circ} \mathrm{C}$ during at least $24 \mathrm{~h}$ (data not shown). In this context, it is well reported that PVA hydrogels become unstable at temperatures above $50{ }^{\circ} \mathrm{C}[39,40]$. The loss of 3D structure of the lenses may facilitate enzyme leakage thus resulting in a decrease of the activity. Based on the above data, we selected $30^{\circ} \mathrm{C}$ to assess the operational stability of the biocatalyst for neo-FOS synthesis, as a compromise between enzyme activity and stability.

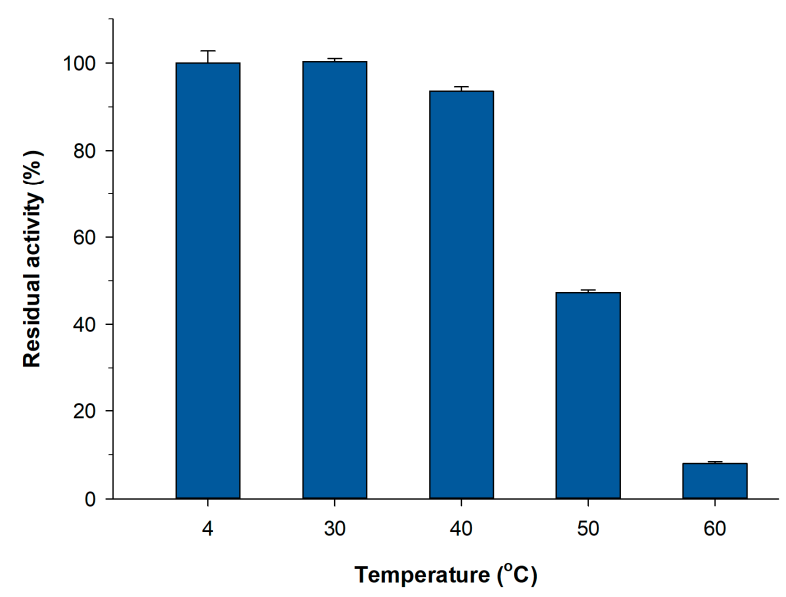

Figure 5. Thermostability of immobilized pXd-INV in PVA. Incubation conditions: $100 \mathrm{mM}$ sodium acetate buffer ( $\mathrm{pH} 5.0), 24 \mathrm{~h}$. 


\subsection{Kinetics of Neo-FOS Formation by Entrapped $p X d-I N V$}

The kinetics of FOS formation with the PVA-entrapped enzyme was analyzed using $600 \mathrm{~g} / \mathrm{L}$ sucrose as substrate at $30^{\circ} \mathrm{C}$. Figure 6 represents the formation of the different products as a function of sucrose consumption. Maximum FOS production was reached when approximately $86 \%$ of the initial sucrose had disappeared, as occurred with the soluble enzyme [12]. At this point, the immobilized pXd-INV yielded $18.9 \%(w / w)$ FOS $(113.5 \mathrm{~g} / \mathrm{L})$, of which $59.1 \mathrm{~g} / \mathrm{L}$ corresponded to neokestose, $30.2 \mathrm{~g} / \mathrm{L}$ to 1 -kestose, $11.6 \mathrm{~g} / \mathrm{L}$ to neonystose, and $12.6 \mathrm{~g} / \mathrm{L}$ to blastose.

We confirmed that blastose was formed by hydrolysis of neokestose, as the concentration of this disaccharide increased up to $30.5 \mathrm{~g} / \mathrm{L}$ concomitant with the sharp decrease of neokestose at the end of the reaction. This value represents a notable concentration of blastose considering that by now the largest production reported of this disaccharide was $34 \mathrm{~g} / \mathrm{L}$ using the Cladosporium cladosporioides mycelium-bound transfructosylation activity [38]. The sharp decrease of FOS concentration observed after $85-90 \%$ consumption of sucrose was also observed with the soluble native enzyme [12] and is typical in the preparation of FOS with other $\beta$-fructofuranosidases [41].

It is worth noting that the maximum FOS concentration (18.9\%) was significantly lower than the obtained with the soluble enzyme (29\%) [42]. This fact might be related with the hydrophilic microenvironment of the PVA lenses, which could favour the hydrolysis in detriment of the transfructosylation. The effect of the microenvironment of the carrier on the transferase to hydrolysis ratio has been also reported in previous works [30,43-46]. In this context, the amount of blastose synthesized by the immobilized pXd-INV was higher than the reported with the recombinant soluble enzyme ( $30 \mathrm{~g} / \mathrm{L}$ vs. $8 \mathrm{~g} / \mathrm{L})$, which is in accordance as it is obtained in a hydrolytic process.

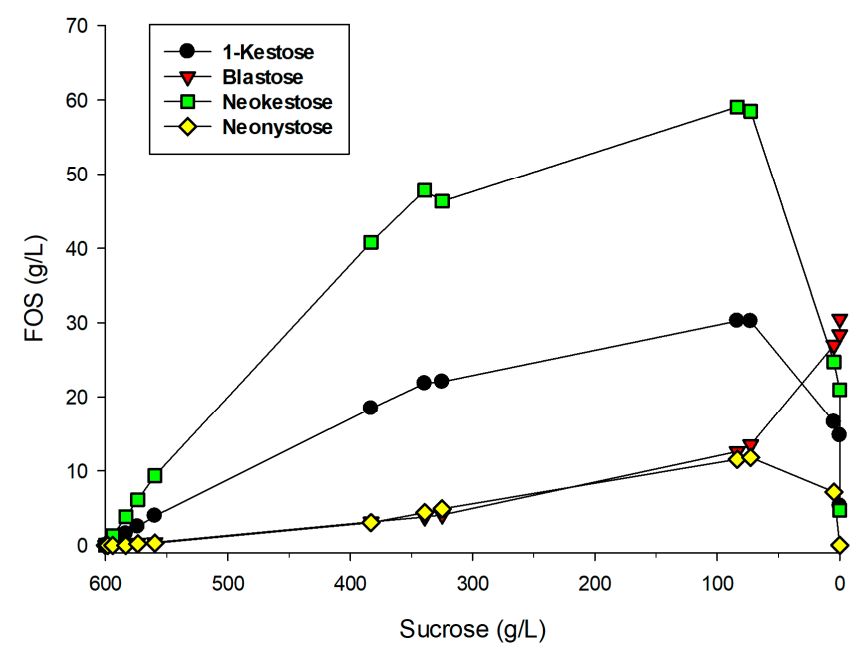

Figure 6. Kinetics of FOS formation with entrapped pXd-INV in PVA. Reaction conditions: $600 \mathrm{~g} / \mathrm{L}$ sucrose, $100 \mathrm{mM}$ sodium acetate buffer ( $\mathrm{pH} 5.0), 30^{\circ} \mathrm{C}$.

\subsection{Operational Stability of Immobilized $p X d-I N V$ for Neo-FOS Production}

We performed seven cycles of $26 \mathrm{~h}$ at $30{ }^{\circ} \mathrm{C}$ using $600 \mathrm{~g} / \mathrm{L}$ as substrate in a batch reactor. Between cycles, the lenses were thoroughly washed with the reaction buffer to remove any remaining sugars. The production of the different FOS is represented in Figure 7. Under the assayed conditions, the conversion of sucrose was approximately $23 \%$, which implies that it was a bit far from the optimum FOS yield (Figure 6). However, the present study was very valuable to determine if these PVA biocatalysts could be reused for the industrial production of neo-FOS a. As shown in Figure 7, the concentration of the main reaction products was maintained nearly constant during the seven reaction cycles. 
The excellent operational stability of the lens-shaped PVA biocatalysts seems to be related with the fact that the lenses apparently maintained their original shape during the study. The operational stability of immobilized enzymes for FOS synthesis has been studied by different groups [47]. Satisfactory results have been obtained, among other methods, by entrapment in alginate followed by a drying process [48], cross-linking in presence of chitosan [49], glutaraldehyde-activated chitosan [50] or adsorption onto niobium ore [51].

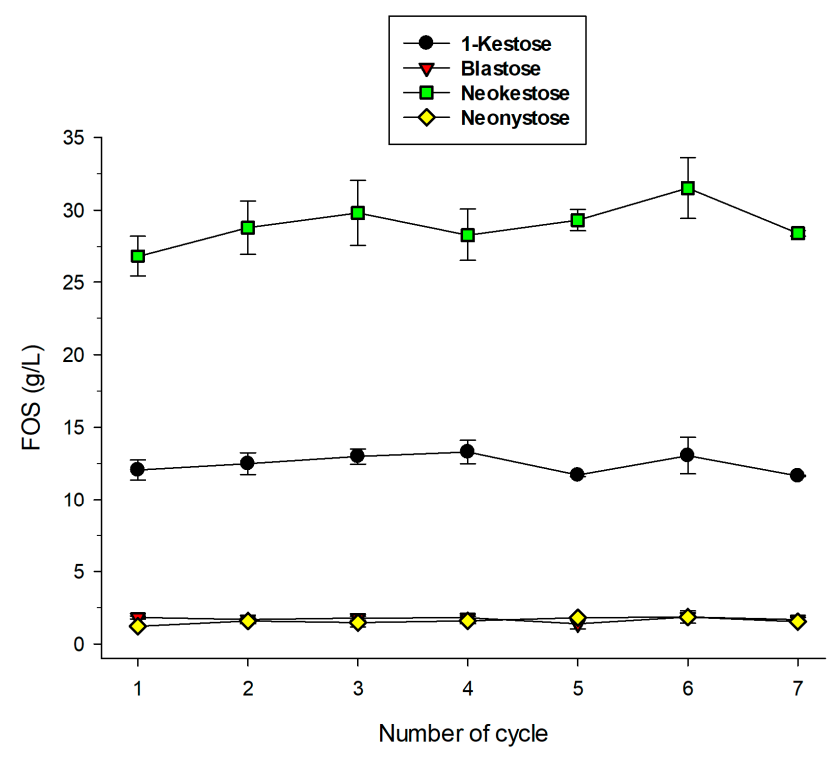

Figure 7. Operational stability of immobilized biocatalyst. Reaction conditions per cycle: $600 \mathrm{~g} / \mathrm{L}$ sucrose in $100 \mathrm{mM}$ sodium acetate buffer (pH 5.0), $26 \mathrm{~h}, 30^{\circ} \mathrm{C}$.

\section{Materials and Methods}

\subsection{Materials}

Sucrose was from Scharlau. Polyvinyl alcohol (PVA) (99\% hydrolyzed, average MW 130,000) was purchased from Sigma Aldrich (Madrid, Spain). Fructose was from Merck and 1-kestose was from TCI. Neokestose, 6-kestose, neonystose and blastose were synthesized according to previous works $[9,38,52]$. All other reagents and solvents were of the highest purity available.

\section{2. $\beta$-Fructofuranosidase Activity Source}

The $\beta$-fructofuranosidase from Xanthophyllomyces dendrorhous ATCC MYA-131 (Xd-INV) was expressed in Pichia pastoris as previously reported [12]. Basically, the gene Xd-INV (GenBank accession no. FJ539193.2) fused to the Saccharomyces cerevisiae MF $\alpha$ secretion signal sequence was cloned in plasmid pIB4 (construction QDNS-pIB4) and included in P. pastoris. Transformants were grown in 50 $\mathrm{mL}$ of Buffered Minimal Glycerol (BMG), yeast nitrogen base w/o amino acids $1.34 \%$, biotin $4 \times 10^{-5} \%$, glycerol $1 \%, 50 \mathrm{mM}$ potassium phosphate buffer, $\mathrm{pH}$ 6.0) during $24 \mathrm{~h}$ and then in $400 \mathrm{~mL}$ of Buffered Minimal Methanol (BMM) the same as BMG but containing 0.5\% methanol instead of glycerol) for $35 \mathrm{~h}$, giving approximately $21 \mathrm{U} / \mathrm{mL}$ of $\beta$-fructofuranosidase activity per $\mathrm{mL}$ of culture. The extracellular $\beta$-fructofuranosidase activity ( $\mathrm{pXd}$-INV) was purified by tangential concentration followed by DEAE-Sephacel chromatography. Active fractions were concentrated using Microcon YM-10 (Amicon) filters $(0.7 \mathrm{~mL} ; 4220 \mathrm{U} / \mathrm{mL} ; 5.8 \mathrm{mg} / \mathrm{mL})$ and stored at $-70{ }^{\circ} \mathrm{C}$.

\subsection{Entrapment of $\beta$-Fructofuranosidase in PVA Lenses}

The PVA solution $(10 \% w / v)$ was prepared in $100 \mathrm{mM}$ sodium acetate buffer ( $\mathrm{pH} 5.0)$ at $90^{\circ} \mathrm{C}$ under magnetic stirring for $45 \mathrm{~min}$ [53]. Enzyme entrapment was carried out at room temperature 
by directly adding the enzyme to the PVA solution under magnetic stirring. Two different enzyme loadings were assayed (7.1 and 16.9 enzyme units per $\mathrm{mL}$ of PVA solution). The amount of enzyme was adjusted by diluting the enzyme stock solution (in $20 \mathrm{mM}$ Tris- $\mathrm{HCl} \mathrm{pH} \mathrm{7.0)} \mathrm{with} 100 \mathrm{mM}$ sodium acetate buffer (pH 5.0) and measuring the activity by the 3,5-dinitrosalicylic acid (DNS) assay. Lenses were produced by pumping the mixture through a syringe pump volume dispenser (NewERA model NE-300) into a 96-well microplate. Lenses were made by dripping 4 drops of the PVA solution in each well and then dried overnight at $50{ }^{\circ} \mathrm{C}$. After that, lenses were hydrated in $100 \mathrm{mM}$ sodium acetate buffer (pH 5.0) until constant weight. The average volume of each lens was calculated according to the total number of drops dispensed, the drops used for the production of each lens and the total volume of solution dispensed. Lens volume was determined using the following equation:

Lens volume $(\mu L)=($ volume dispensed/number of drops dispensed $) \times$ number of drops in each lens

\subsection{Enzyme Activity Assay}

$\beta$-Fructofuranosidase activity was determined by detection of reducing sugars with a modified 3,5-dinitrosalicylic acid (DNS) method adapted to a 96-well microplate scale [37]. The reaction mixture contained $45 \mu \mathrm{L}$ of a $100 \mathrm{mg} / \mathrm{mL}$ sucrose solution in $100 \mathrm{mM}$ sodium acetate buffer (pH 5.0) and $5 \mu \mathrm{L}$ of a conveniently diluted enzyme solution. The reaction was incubated at $50{ }^{\circ} \mathrm{C}$ for $20 \mathrm{~min}$, and then stopped by adding $50 \mu \mathrm{L}$ of 3,5-dinitrosalicylic acid (DNS). The quantification of reducing sugars was carried out with a calibration curve of D-glucose, and one unit of activity $(\mathrm{U})$ corresponded to the release of one $\mu \mathrm{mol}$ of reducing sugars per minute. The apparent activity of the immobilized biocatalysts was determined using a methodology developed in our group [36]. Basically, the lens-shaped PVA particles was incubated with $500 \mu \mathrm{L}$ of $100 \mathrm{~g} / \mathrm{L}$ sucrose solution in a micro-centrifuge filter tube (Spin- $X^{\circledR}$, $0.45 \mu \mathrm{m}$, Costar, Corning Inc., Corning, NY, USA) at the desired temperature for $60 \mathrm{~min}$ under vigorous agitation $(900 \mathrm{rpm})$. The reaction mixture was separated from the biocatalyst by centrifugation at $2000 \times g$. Inactivation of the possible lixiviated enzyme was carried out by adding $500 \mu \mathrm{L}$ of $0.4 \mathrm{M}$ sodium carbonate. Finally, reducing sugars were measured by the DNS assay as described above.

\subsection{Microscale Assay for the Operational Stability of Immobilized $p X d-I N V$}

The operational stability of the immobilized biocatalysts was assayed following a previously described microscale assay [36]. One PVA lens was placed in a filtered micro-centrifuge tube (Spin- $X^{\circledR}$, $0.45 \mu \mathrm{m}$, Costar, Corning Inc., Corning, NY, USA) with $500 \mu \mathrm{L}$ of a $100 \mathrm{mg} / \mathrm{mL}$ sucrose solution. Reactions were carried out at $50^{\circ} \mathrm{C}$ and $\mathrm{pH} 5.0$ for $20 \mathrm{~min}$. Centrifugation was carried out at $2000 \times g$ to separate the lens from the reaction medium. The amount of reducing sugars was measured by the DNS method, as described before. The biocatalysts were washed three times with $100 \mathrm{mM}$ sodium acetate buffer ( $\mathrm{pH}$ 5.0) between cycles. Experiments were performed in triplicate to calculate the standard deviations.

\subsection{Thermostability of the Immobilized PVA Particles}

The thermostability of the lens-shaped PVA particles was analyzed by incubating the immobilized biocatalyst at different temperatures $\left(4-60^{\circ} \mathrm{C}\right)$ for $24 \mathrm{~h}$ in $100 \mathrm{mM}$ sodium acetate buffer ( $\mathrm{pH}$ 5.0). Residual activity was measured using the DNS assay under standard conditions $\left(50{ }^{\circ} \mathrm{C}, \mathrm{pH} 5.0\right)$. Experiments were performed in triplicate to calculate the standard deviations.

\subsection{Analysis of Fructooligosacharides by HPAEC-PAD}

The identification and quantification of FOS was carried out by High Performance Anion-Exchange Chromatography with Pulsed Amperometric Detection (HPAEC-PAD, Dionex ICS3000 system, Sunnyvale, CA, USA) and a CarboPack PA-1 column $(4 \times 250 \mathrm{~mm})$ connected to a PA-1 guard column. The method was adapted from Campbell et al. [54]. Initial mobile phase was $100 \mathrm{mM} \mathrm{NaOH}$ at $1 \mathrm{~mL} / \mathrm{min}$ and it was maintained for $8 \mathrm{~min}$. Then, a gradient from 100 
to $88 \% 100 \mathrm{mM} \mathrm{NaOH}$ and from 0 to $12 \% 100 \mathrm{mM} \mathrm{NaOH} / 600 \mathrm{mM}$ sodium acetate was performed in $22 \mathrm{~min}$. These conditions were kept for $6 \mathrm{~min}$ and then the eluents concentration was changed to $50 \% 100 \mathrm{mM} \mathrm{NaOH}$ and $50 \% 100 \mathrm{mM} \mathrm{NaOH} / 600 \mathrm{mM}$ sodium acetate. Eluents were degassed by flushing with helium and peaks were analyzed using Chromeleon software.

\subsection{Production of Fructooligosacharides by Immobilized $p X d-I N V$}

Lenses of immobilized pXd-INV were added to a $600 \mathrm{mg} / \mathrm{mL}$ sucrose solution in $100 \mathrm{mM}$ sodium acetate buffer, $\mathrm{pH}$ 5.0, until reaching a final activity of $1 \mathrm{U} / \mathrm{mL}$. The reaction mixture was incubated at $30^{\circ} \mathrm{C}$ in an orbital stirrer, and aliquots $(100 \mu \mathrm{L})$ were taken out at different times and inactivated with $0.4 \mathrm{M} \mathrm{Na}_{2} \mathrm{CO}_{3}$. The formation of the different FOS was analyzed by HPAEC-PAD.

\subsection{Operational Stability of Immobilized $p X d-I N V$ for Neo-FOS Production}

The operational stability of the immobilized biocatalysts was assayed following neo-FOS production. One lens-shaped PVA particle $(0.3 \mathrm{U})$ was placed in a filtered micro-centrifuge tube (Spin- $\mathrm{X}^{\circledR}, 0.45 \mu \mathrm{m}$, Costar, Corning Inc, Corning, NY, USA) with $340 \mu \mathrm{L}$ of a $600 \mathrm{mg} / \mathrm{mL}$ sucrose solution in $100 \mathrm{mM}$ sodium acetate buffer ( $\mathrm{pH}$ 5.0). The mixture was incubated at $30{ }^{\circ} \mathrm{C}$ for $26 \mathrm{~h}$ in a Thermoshaker (model TS-100, bioSan, Nebikon, Switzerland) at $900 \mathrm{rpm}$. The tube was then centrifuged at $2000 \times g$ for 2 min to separate the supernatant. To inactivate any possible lixiviated enzyme, the supernatant was diluted with $340 \mu \mathrm{L}$ of $0.4 \mathrm{M}$ sodium carbonate solution. Samples were diluted 1:500 before analyzing the FOS composition by HPAEC-PAD as described before. Experiments were performed in triplicate to calculate the standard deviations. Between cycles, the lens-shaped biocatalysts were washed three times with $100 \mathrm{mM}$ sodium acetate buffer (pH 5.0) followed by centrifugation at $2000 \times g$ for $2 \mathrm{~min}$.

\section{Conclusions}

The PVA-entrapped biocatalysts of pXd-INV displayed a notable recovery of activity and excellent operational stability at $30^{\circ} \mathrm{C}$ during at least $180 \mathrm{~h}$. These immobilized biocatalystscould be employed for the high-scale production of neo-FOS as well as for the fructosylation of different bioactive compounds.

Author Contributions: M.H.R. and F.J.P. conceived and designed the experiments; N.M. performed most of the experiments; D.F.-P. contributed operational stability of biocatalysts; F.V.C. contributed HPAEC-PAD analysis; M.G.-P. and M.F.-L. contributed preparation and characterization of pXd-INV; A.O.B. contributed discussion of results; F.J.P. wrote the paper.

Acknowledgments: This work was supported by grants from the Spanish Ministry of Economy, Industry and Competitiveness (Grants BIO2016-76601-C3-1-R and BIO2016-76601-C3-3-R). We thank the support of COST-Action CM1303 on Systems Biocatalysis. M.G.-P. thanks the Spanish Ministry of Education for FPU Grant. We acknowledge support of the publication fee by the CSIC Open Access Publication Support Initiative through its Unit of Information Resources for Research (URICI).

Conflicts of Interest: The authors declare no conflict of interest.

\section{References}

1. Plou, F.J.; Gómez de Segura, A.; Ballesteros, A. Application of glycosidases and transglycosidases for the synthesis of oligosaccharides. In Industrial Enzymes: Structure, Function and Application; Polaina, J., MacCabe, A.P., Eds.; Springer: New York, NY, USA, 2007; pp. 141-157.

2. Gibson, G.R.; Probert, H.M.; Van Loo, J.; Rastall, R.A.; Roberfroid, M.B. Dietary modulation of the human colonic microbiota: Updating the concept of prebiotics. Nutr. Res. Rev. 2004, 17, 259-275. [CrossRef] [PubMed]

3. Singh, S.P.; Jadaun, J.S.; Narnoliya, L.K.; Pandey, A. Prebiotic oligosaccharides: Special focus on fructooligosaccharides, its biosynthesis and bioactivity. Appl. Biochem. Biotech. 2017, 183, 613-635. [CrossRef] [PubMed] 
4. Hidaka, H.; Eida, T.; Takizawa, T.; Tokunaga, T.; Tashiro, Y. Effects of fructooligosaccharides on intestinal flora and human health. Bifidobact. Microflora 1986, 5, 37-50. [CrossRef]

5. Cruz, R.; Cruz, V.D.; Belini, M.Z.; Belote, J.G.; Vieira, C.R. Production of fructooligosaccharides by the mycelia of Aspergillus japonicus immobilized in calcium alginate. Biores. Technol. 1998, 65, 139-143. [CrossRef]

6. Flores-Maltos, D.A.; Mussatto, S.I.; Contreras-Esquivel, J.C.; Rodríguez-Herrera, R.; Teixeira, J.A.; Aguilar, C.N. Biotechnological production and application of fructooligosaccharides. Crit. Rev. Biotechnol. 2016, 36, 259-267. [CrossRef] [PubMed]

7. Kilian, S.; Kritzinger, S.; Rycroft, C.; Gibson, G.; du Preez, J. The effects of the novel bifidogenic trisaccharide, neokestose, on the human colonic microbiota. World J. Microb. Biot. 2002, 18, 637-644. [CrossRef]

8. Lim, J.S.; Lee, J.H.; Kang, S.W.; Park, S.W.; Kim, S.W. Studies on production and physical properties of neo-FOS produced by co-immobilized Penicillium citrinum and neo-fructosyltransferase. Eur. Food Res. Technol. 2007, 225, 457-462. [CrossRef]

9. Linde, D.; Macias, I.; Fernández-Arrojo, L.; Plou, F.J.; Jiménez, A.; Fernández-Lobato, M. Molecular and biochemical characterization of a $\beta$-fructofuranosidase from Xanthophyllomyces dendrorhous. Appl. Environ. Microbiol. 2009, 75, 1065-1073. [CrossRef] [PubMed]

10. Ramirez-Escudero, M.; Gimeno-Perez, M.; Gonzalez, B.; Linde, D.; Merzdo, Z.; Fernandez-Lobato, M.; Sanz-Aparicio, J. Structural analysis of $\beta$-fructofuranosidase from Xanthophyllomyces dendrorhous reveals unique features and the crucial role of n-glycosylation in oligomerization and activity. J. Biol. Chem. 2016, 291, 6843-6857. [CrossRef] [PubMed]

11. Linde, D.; Rodríguez-Colinas, B.; Estévez, M.; Poveda, A.; Plou, F.J.; Fernández Lobato, M. Analysis of neofructooligosaccharides production mediated by the extracellular $\beta$-fructofuranosidase from Xanthophyllomyces dendrorhous. Biores. Technol. 2012, 109, 123-130. [CrossRef] [PubMed]

12. Gimeno-Pérez, M.; Linde, D.; Fernández-Arrojo, L.; Plou, F.J.; Fernández-Lobato, M. Heterologous overproduction of $\beta$-fructofuranosidase from yeast Xanthophyllomyces dendrorhous, an enzyme producing prebiotic sugars. Appl. Microbiol. Biotechnol. 2015, 99, 3459-3467. [CrossRef] [PubMed]

13. Gimeno-Perez, M.; Santos-Moriano, P.; Fernandez-Arrojo, L.; Poveda, A.; Jimenez-Barbero, J.; Ballesteros, A.O.; Fernandez-Lobato, M.; Plou, F.J. Regioselective synthesis of neo-erlose by the $\beta$-fructofuranosidase from Xanthophyllomyces dendrorhous. Process Biochem. 2014, 49, 423-429. [CrossRef]

14. Madhavan, A.; Sindhu, R.; Binod, P.; Sukumaran, R.K.; Pandey, A. Strategies for design of improved biocatalysts for industrial applications. Biores. Technol. 2017, 245, 1304-1313. [CrossRef] [PubMed]

15. Sheldon, R.A. Enzyme immobilization: The quest for optimum performance. Adv. Synth. Catal. 2007, 349, 1289-1307. [CrossRef]

16. Torres-Salas, P.; Del Monte-Martinez, A.; Cutiño-Avila, B.; Rodriguez-Colinas, B.; Alcalde, M.; Ballesteros, A.O.; Plou, F.J. Immobilized biocatalysts: Novel approaches and tools for binding enzymes to supports. Adv. Mater. 2011, 23, 5275-5282. [CrossRef] [PubMed]

17. Torres, P.; Reyes-Duarte, D.; Lopez-Cortes, N.; Ferrer, M.; Ballesteros, A.; Plou, F.J. Acetylation of vitamin E by Candida antarctica lipase B immobilized on different carriers. Process Biochem. 2008, 43, 145-153. [CrossRef]

18. Datta, S.; Christena, L.R.; Rajaram, Y.R.S. Enzyme immobilization: An overview on techniques and support materials. 3 Biotech 2013, 3, 1-9. [CrossRef] [PubMed]

19. Santos-Moriano, P.; Monsalve-Ledesma, L.; Ortega-Munoz, M.; Fernandez-Arrojo, L.; Ballesteros, A.O.; Santoyo-Gonzalez, F.; Plou, F.J. Vinyl sulfone-activated silica for efficient covalent immobilization of alkaline unstable enzymes: Application to levansucrase for fructooligosaccharide synthesis. RSC Adv. 2016, 6, 64175-64181. [CrossRef]

20. Santos-Moriano, P.; Woodley, J.M.; Plou, F.J. Continuous production of chitooligosaccharides by an immobilized enzyme in a dual-reactor system. J. Mol. Catal. B Enzym. 2016, 133, 211-217. [CrossRef]

21. Kahar, U.M.; Sani, M.H.; Chan, K.G.; Goh, K.M. Immobilization of $\alpha$-amylase from Anoxybacillus sp. SK3-4 on ReliZyme and Immobead supports. Molecules 2016, 21, 1196. [CrossRef] [PubMed]

22. Carević, M.; Ćorović, M.; Mihailović, M.; Banjanac, K.; Milisavljević, A.; Veličković, D.; Bezbradica, D. Galacto-oligosaccharide synthesis using chemically modified $\beta$-galactosidase from Aspergillus oryzae immobilised onto macroporous amino resin. Int. Dairy J. 2016, 54, 50-57. [CrossRef]

23. Gomez de Segura, A.; Alcalde, M.; Bernabe, M.; Ballesteros, A.; Plou, F.J. Synthesis of methyl $\alpha$-D-glucooligosaccharides by entrapped dextransucrase from Leuconostoc mesenteroides B-1299. J. Biotechnol. 2006, 124, 439-445. [CrossRef] [PubMed] 
24. Alcalde, M.; Plou, F.J.; de Segura, A.G.; Remaud-Simeon, M.; Willemot, R.M.; Monsan, P.; Ballesteros, A. Immobilization of native and dextran-free dextransucrases from Leuconostoc mesenteroides NRRL B-512F for the synthesis of glucooligosaccharides. Biotechnol. Tech. 1999, 13, 749-755. [CrossRef]

25. Gadea, J.L.; Cesteros, L.C.; Katime, I. Chemical-physical behavior of hydrogels of poly(vinyl alcohol) and poly(ethylene glycol). Eur. Polym. J. 2013, 49, 3582-3589. [CrossRef]

26. Nuneslentik, M.A.P.; Gois, P.M.P.; Rosa, M.E.; Martins, S.; Fernandes, P.C.B.; Ribeiro, M.H.L. Boronic acids as efficient cross linkers for PVA: Synthesis and application of tunable hollow microspheres in biocatalysis. Tetrahedron 2016, 72, 7293-7305.

27. Durieux, A.; Nicolay, X.; Simon, J.P. Continuous malolactic fermentation by Oenococcus oeni entrapped in LentiKats. Biotechnol. Lett. 2000, 22, 1679-1684. [CrossRef]

28. Schlieker, M.; Vorlop, K.-D. A novel immobilization method for entrapment: LentiKats. In Immobilization of Enzymes and Cells; Guisan, J.M., Ed.; Springer: Heidelberg, Germany, 2006; pp. 333-343.

29. Ariga, O.; Kubo, T.; Sano, Y. Effective diffusivity of glucose in PVA hydrogel. J. Ferment. Bioeng. 1994, 78, 200-201. [CrossRef]

30. Gómez de Segura, A.; Alcalde, M.; Plou, F.J.; Remaud-Simeon, M.; Monsan, P.; Ballesteros, A. Encapsulation in LentiKats of dextransucrase from Leuconostoc mesenteroides NRRL B-1299, and its effect on product selectivity. Biocatal. Biotransform. 2003, 21, 325-331. [CrossRef]

31. Imai, K.; Shiomi, T.; Uchida, K.; Miya, M. Immobilization of enzyme into poly(vinyl alcohol) membrane. Biotechnol. Bioeng. 1986, 28, 1721-1726. [CrossRef] [PubMed]

32. Nunes, M.A.P.; Rosa, M.E.; Fernandes, P.C.B.; Ribeiro, M.H.L. Operational stability of naringinase PVA lens-shaped microparticles in batch stirred reactors and mini packed bed reactors-one step closer to industry. Biores. Technol. 2014, 164, 362-370. [CrossRef] [PubMed]

33. Lozinsky, V.I.; Plieva, F.M. Poly(vinyl alcohol) cryogels employed as matrices for cell immobilization. 3. Overview of recent research and developments. Enzyme Microb. Tech. 1998, 23, 227-242. [CrossRef]

34. Luo, M.; Wang, W.; Zhao, Q.; Li, M.; Chen, Y.; Lu, Z.; Liu, K.; Wang, D. Chemiluminescence biosensor for hydrogen peroxide determination by immobilizing horseradish peroxidase onto PVA-CO-PE nanofiber membrane. Eur. Polym. J. 2017, 91, 307-314. [CrossRef]

35. Cao, Y.; Liu, F.; Chen, Y.; Yu, T.; Lou, D.; Guo, Y.; Li, P.; Wang, Z.; Ran, H. Drug release from core-shell PVA/silk fibroin nanoparticles fabricated by one-step electrospraying. Sci. Rep. 2017, 7, 11913. [CrossRef] [PubMed]

36. Fernandez-Arrojo, L.; Santos-Moriano, P.; Rodriguez-Colinas, B.; Ballesteros, A.O.; Plou, F.J. Micro-scale procedure for enzyme immobilization screening and operational stability assays. Biotechnol. Lett. 2015, 37, 1593-1600. [CrossRef] [PubMed]

37. Ghazi, I.; Fernandez-Arrojo, L.; Garcia-Arellano, H.; Ferrer, M.; Ballesteros, A.; Plou, F.J. Purification and kinetic characterization of a fructosyltransferase from Aspergillus aculeatus. J. Biotechnol. 2007, 128, $204-211$. [CrossRef] [PubMed]

38. Zambelli, P.; Fernandez-Arrojo, L.; Romano, D.; Santos-Moriano, P.; Gimeno-Perez, M.; Poveda, A.; Gandolfi, R.; Fernandez-Lobato, M.; Molinari, F.; Plou, F.J. Production of fructooligosaccharides by mycelium-bound transfructosylation activity present in Cladosporium cladosporioides and Penicilium sizovae. Process Biochem. 2014, 49, 2174-2180. [CrossRef]

39. Alves, M.H.; Jensen, B.E.B.; Smith, A.A.A.; Zelikin, A.N. Poly(vinyl alcohol) physical hydrogels: New vista on a long serving biomaterial. Macromol. Biosci. 2011, 11, 1293-1313. [CrossRef] [PubMed]

40. Rescignano, N.; Fortunati, E.; Montesano, S.; Emiliani, C.; Kenny, J.M.; Martino, S.; Armentano, I. PVA bio-nanocomposites: A new take-off using cellulose nanocrystals and PLGA nanoparticles. Carbohydr. Polym. 2014, 99, 47-58. [CrossRef] [PubMed]

41. Gutierrez-Alonso, P.; Fernandez-Arrojo, L.; Plou, F.J.; Fernandez-Lobato, M. Biochemical characterization of a $\beta$-fructofuranosidase from Rhodotorula dairenensis with transfructosylating activity. FEMS Yeast Res. 2009, 9, 768-773. [CrossRef] [PubMed]

42. Gutierrez-Alonso, P.; Gimeno-Perez, M.; Ramirez-Escudero, M.; Plou, F.J.; Sanz-Aparicio, J.; Fernandez-Lobato, M. Molecular characterization and heterologous expression of a Xanthophyllomyces dendrorhous $\alpha$-glucosidase with potential for prebiotics production. Appl. Microbiol. Biot. 2016, 100, 3125-3135. [CrossRef] [PubMed] 
43. Ghazi, I.; de Segura, A.G.; Fernandez-Arrojo, L.; Alcalde, M.; Yates, M.; Rojas-Cervantes, M.L.; Plou, F.J.; Ballesteros, A. Immobilisation of fructosyltransferase from Aspergillus aculeatus on epoxy-activated Sepabeads EC for the synthesis of fructo-oligosaccharides. J. Mol. Catal. B Enzym. 2005, 35, 19-27. [CrossRef]

44. Rodrigues, R.C.; Ortiz, C.; Berenguer-Murcia, A.; Torres, R.; Fernández-Lafuente, R. Modifying enzyme activity and selectivity by immobilization. Chem. Soc. Rev. 2013, 42, 6290-6307. [CrossRef] [PubMed]

45. Hill, A.; Karboune, S.; Mateo, C. Immobilization and stabilization of levansucrase biocatalyst of high interest for the production of fructooligosaccharides and levan. J. Chem. Technol. Biot. 2016, 91, 2440-2448. [CrossRef]

46. Palomo, J.M. Modulation of enzymes selectivity via immobilization. Curr. Org. Synth. 2009, 6, 1-14. [CrossRef]

47. Plou, F.J.; Fernandez-Arrojo, L.; Santos-Moriano, P.; Ballesteros, A.O. Application of immobilized enzymes for the synthesis of bioactive fructooligosaccharides. In Food Oligosaccharides: Production, Analysis and Bioactivity; Moreno, F.J., Sanz, M.L., Eds.; Wiley Blackwell: Hoboken, NJ, USA, 2014; pp. 200-216.

48. Fernandez-Arrojo, L.; Rodriguez-Colinas, B.; Gutierrez-Alonso, P.; Fernandez-Lobato, M.; Alcalde, M.; Ballesteros, A.O.; Plou, F.J. Dried alginate-entrapped enzymes (DALGEEs) and their application to the production of fructooligosaccharides. Process Biochem. 2013, 48, 677-682. [CrossRef]

49. Mouelhi, R.; Abidi, F.; Marzouki, M.N. An improved method for the production of fructooligosaccharides by immobilized $\beta$-fructofuranosidase from Sclerotinia sclerotiorum. Biotechnol. Appl. Biochem. 2016, 63, 281-291. [CrossRef] [PubMed]

50. Lorenzoni, A.S.G.; Aydos, L.F.; Klein, M.P.; Rodrigues, R.C.; Hertz, P.F. Fructooligosaccharides synthesis by highly stable immobilized $\beta$-fructofuranosidase from Aspergillus aculeatus. Carbohydr. Polym. 2014, 103, 193-197. [CrossRef] [PubMed]

51. Aguiar-Oliveira, E.; Maugeri, F. Characterization of the immobilized fructosyltranferase from Rhodotorula sp. Int. J. Food Eng. 2010, 6. [CrossRef]

52. Alvaro-Benito, M.; de Abreu, M.; Fernandez-Arrojo, L.; Plou, F.J.; Jimenez-Barbero, J.; Ballesteros, A.; Polaina, J.; Fernandez-Lobato, M. Characterization of a $\beta$-fructofuranosidase from Schwanniomyces occidentalis with transfructosylating activity yielding the prebiotic 6-kestose. J. Biotechnol. 2007, 132, 75-81. [CrossRef] [PubMed]

53. Nunes, M.A.P.; Vila-Real, H.; Fernandes, P.C.B.; Ribeiro, M.H.L. Immobilization of naringinase in PVA-alginate matrix using an innovative technique. Appl. Biochem. Biotech. 2010, 160, 2129-2147. [CrossRef] [PubMed]

54. Campbell, J.M.; Bauer, L.L.; Fahey, G.C.; Hogarth, A.J.C.L.; Wolf, B.W.; Hunter, D.E. Selected fructooligosaccharide (1-kestose, nystose, and $1 \mathrm{~F}-\beta$-fructofuranosylnystose) composition of foods and feeds. J. Agric. Food Chem. 1997, 45, 3076-3082. [CrossRef] 